Research Articles

\title{
Life Cycle Flow (LCF) Application to Evaluate the Real Estate Investment in Residential Buildings with Tax Benefit Incentives in Cases of Positive Externalities
}

\author{
Mattia Iotti and Giuseppe Bonazzi \\ Department of Civil Engineering, Environment, \\ Territory and Architecture (DICATeA), University of Parma, Parma, Italy
}

\author{
Article history \\ Received: 31-03-2015 \\ Revised: 26-04-2015 \\ Accepted: 22-06-2015 \\ Corresponding Author: \\ Mattia Iotti \\ Department of Civil Engineering, \\ Environment, Territory and \\ Architecture (DICATeA), \\ University of Parma, Parma, Italy \\ Email: mattia.iotti@unipr.it
}

\begin{abstract}
Investing in the main home is an important form of investment for families and represented one of the main family assets in Italy in the second half of the 20th century. The evaluation of the convenience of the house purchase needs to consider that technologies in construction have undergone a rapid change in recent times that proposes an approach to sustainable building technologies, such as dry construction systems that can reduce energy consumption over time. Moreover, these construction systems are encouraged with tax deductions from the state, that is, financing with public spending via a tax benefit, which recognizes the role of externalities of investments in sustainable construction. The article would apply Life Cycle Flow (LCF) model to a residential building; LCF is based on the Life Cycle Cost (LCC) model and adapted to assess a real estate investment, such as a residential building for private use, taking into account the effects of a tax benefit. The model quantifies the cost of satisfying consumers' housing needs in the long run. The model takes into account the absorption of financial resources at all stages of property investment. The proposed LCF approach quantifies an average discounted cash outflow per year and an average discounted cash outflow per year per surface unit in square meters; thus, it is possible to compare project alternatives and choose the alternative that minimizes the absorption of financial resources in the long run. In this article, the LCF model is applied to three project alternatives and highlights the energy savings in the long run for consumption choices and the importance of tax benefits for the reduction of the cash outflow for a family in long-term housing. Given the results of the research, the proposed LCF model can be applied on a larger scale, in particular, to quantify social welfare generated by tax benefits financed with public spending, in terms of economic activation and assessing environmental externalities.
\end{abstract}

Keywords: Life Cycle Flow (LCF), Life Cycle Cost (LCC), Residential Building, Positive Externalities, Dry Stratified Construction Technology

\section{Introduction}

The objective of this article is to improve the Life Cycle Cost (LCC) analysis applied in several studies for the cost evaluation in the long run both for consumers' and firms' choices. The life cycle approach developed in the article does not take into account economic flows, as in traditional literature for LCC, but considers cash flows in order to develop an approach called Life Cycle Flow (LCF) analysis. The LCF approach developed and applied in this article assesses not only the convenience of management but also financial sustainability in the 
long run. The LCF approach develops a previous approach (Iotti and Bonazzi, 2014a) applied to food processing and follows the LCC method developed by other researchers (Iotti and Bonazzi, 2014b; Strano et al., 2015). This article considers investment in residential construction and aims to quantify the total monetary annual outflow per unit of surface (square meters) charged to the property owner who is also the person living in the building. This work is of interest because it allows the development of the LCF approach in the case of residential housing, including the effects of a tax advantage provided by a variety of laws, including Italian fiscal rules. The LCF approach is usefully applied again for the analysis of the investment in construction because this often has a high initial investment and is characterized by a long life cycle with relevant cash outflows during that time, e.g., for maintenance and energy consumption). Regarding residential building, the choice of investment is made by the consumer at the time of purchase and should consider, in a conscious way, the cash outflows throughout the useful life of the investment. Therefore, it is necessary to consider the financial flows management of the property during time with special attention paid to energy costs. This preliminary assessment, which thus far is rarely performed by consumers, has great importance because the investment in the main home is an important form of investment for consumers and, in Italy, has represented one of the main family assets in the second half of the twentieth century. Moreover, LCF analysis allows consumers to make evaluations taking into account the entire life cycle of the building, in addition, aiming to assess investment alternatives by identifying project investment alternatives that are associated with the least commitment in terms of the absorption of financial resources, not with regard to a instant time or a partial duration time, but considering the entire useful life of the building. The evaluation of the convenience of the house purchase using LCF needs to consider that technologies in construction have changed rapidly in recent years, particularly in the last decade. New technologies propose dry construction systems able to reduce energy consumption over time as sustainable building technologies. In this article, the LCF model is applied to the evaluation of three project alternatives (traditional "wet" construction technologies, sustainable "dry" construction technologies and sustainable "dry" construction technologies with tax benefits) and highlight the energy savings in the long run in consumption choices and, particularly, the importance of tax benefits in the reduction of the cash outflow for a family in long-term housing. In construction, dry stratified technology has particularities in terms of cost, both from the point of view of the project and construction of the work; at the construction site, from the point of view of the cost of building management; during its useful life; and at the end of its useful life when demolition or transformation of manufactured housing is performed. Differences between the performance throughout the life of the building for "dry" technology and traditional "wet" building systems need to be verified and benchmarked to define a parameter of economic choice, specifically identified in the absorption of financial resources, which is evaluated in this article using LCF analysis. Some authors (Imperadori, 2008) showed that, in the past, the application of building systems layered dry was applied only in specialized or niche areas, such as shops, hospitals and commercial buildings, while today, applications of this technique have extended to the field of residential construction. When choosing equipment, such as a car or simple light bulb (Imperadori, 2008), consumers adopt the lowest cost as a discriminating choice approach. Therefore, the application of approaches aimed at quantifying the cash outflow in the long run are applicable for the assessment of housing choices for consumers, given the highly relevant impact of this choice on income and wealth during the whole life of the consumer because a high amount of consumers' wealth is represented by their main home. Residential buildings are investments made often with recourse to financial debt in the form of a secured mortgage on the property. Therefore, the evaluation of LCF becomes useful for quantifying the effect of financial outflow during time, in particular, for repaying financial debts. Moreover, sustainable construction systems are encouraged with tax deductions because the state recognizes the role of externalities for investment in sustainable construction, which are financed using public spending by providing tax benefits.

\section{Materials and Methods}

\section{Literature Review}

The traditional cost accounting approach considers the distinction between fixed costs and variable costs according to the method of direct costing or full costing, generally for a short-term period (Cooper and Kaplan, 1999; Pong and Mitchell, 2006; Al Omiri and Drury, 2007; Costa and Guzzo, 2013; Debnath and Bose, 2014). The Activity-Based Costing (ABC) approach quantifies the total cost of a given product or service by analyzing the all the activities of production. The ABC methodology highlights causal relationships between activities carried out to develop a product, overcoming cost accounting method limits (Cooper and Kaplan, 1991; 1992; Argyris and Kaplan, 1994; Yoshikawa et al., 1994; Shim and Stagliano, 1997) altough the method is 
frequently applied for short-term period analysis. An approach that quantifies cost only considering a singleyear period is not suitable for evaluating long-term investments. To achieve this goal, it is necessary to quantify the cost of production during the total life of the investment, as provided in the LCC approach (Fabrycky and Blanchard, 1991; Artto, 1994; Asiedu and Gu, 1998; Askarany and Smith, 2003) particularly applied to the case of discounted cash flows analysis of durable goods (Notarnicola et al., 2009). In 2002, Society of Environmental Toxicology and Chemistry (SETAC) issued a Code of Practice to define the objectives of the LCC methodology (Rebitzer and Seuring, 2003). LCC is relevant given that the ABC methodology does not discount values in the assessment and does not consider the long-term cost analysis that is of fundamental importance in a capital intensive sector, such as agri-food (Tudisca et al., 2013; Sarno and Barmo, 2014); the method is also important about net financial position repayment analysis (Iotti and Bonazzi, 2015) and even for evaluation of environmental aspects of investment (Notarnicola et al., 2004; Troiano and Marangon, 2010; Lopolito et al., 2011; De Gennaro et al., 2012; Di Trapani et al., 2014; Sgroi et al., 2014; Bonazzi and Iotti, 2014). LCC takes into account all costs, discounted year by year for the entire life of the project, thus long-run cost analysis is frequently applied according to the LCC approach (Schiffauerova and Dale, 2006; Kallunki and Silvola, 2008; Korpi and Ala-Risku, 2008; Srivastava, 2008; Hedeşiu et al., 2012). Traditional appraisal approaches could exclude some phases of the useful life of the project (Gluch and Baumann, 2004); however, the LCC approach allows an assessment of investment projects considering all costs of the life cycle of investment (Dhillon, 1989). Three approaches have been recognized: Conventional LCC, whereby the economic value as an internal cost is strictly considered in terms of the life cycle of a product; environmental LCC, which is always accompanied by a complementary Life Cycle Assessment (LCA) based on an evaluation of all costs, including externalities (Notarnicola et al., 2009; Strano et al., 2013a; 2013b; Chinnici et al., 2013; Fedele et al., 2014; Lanfranchi and Giannetto, 2014; De Luca et al., 2014); and social LCC, which assesses internal and external costs in conjuction with LCA, with the involvement of government agencies not directly responsible for the production system (Ciroth et al., 2008; Lichtenvort et al., 2008; De Luca et al., 2015; Falcone et al., 2015). Among these approaches, the International Organization for Standardization defines LCC as a methodology for the systematic economic appraisal of products/processes (ISO, 2008). To assess the convenience of the realization of an investment in manufactured housing for a generic investment (such as an investment in an entrepreneurial activity, plant or financial asset), LCC can be applied because it takes into account the effects that project may generate for its entire useful life (OT), or for a fixed time horizon $\psi$, such that OT $>\psi$, where OT and $\psi$ are on the time scale, usually with units in years. This distinction between the durations of analysis distinguishes approaches aimed at quantifying the convenience of the realization of the investment; LCC could consider a part of life with a time horizon $\psi<$ OT that can be defined as partial approache, or could consider entire useful life of the investment (i.e., OT = $\psi$ ) that can be defined as comprehensive approaches. The LCC could then consider only a given time horizon $\psi$, defined according to parameters not necessarily related to the physical or technical length of the investment, but more related to the economic dynamics generated by the investment and this is linked to a cause and effect. Consider the case of an investment property that generates economic flows according to a lease expiring time horizon $(\psi)$ or via a project financing type $\mathrm{BOO}$ as a concession until time horizon $(\psi)$. Therefore, comprehensive approaches involve the development of the evaluation until the completion of the physical/technical life to the fulfillment of life OT, which are defined according to parameters related to the physical or technical length of investment and thus not only related to economic dynamics generated by the investment.

\section{Life Cycle Cost (LCC) and Life Cycle Flow (LCF) Approaches}

For the LCC method, it is useful to consider, as several researchers have suggested, all costs and financial flow, during al life cycle of the project (Rebitzer and Seuring, 2003; Iotti and Bonazzi, 2014b; Strano et al., 2015). We would first quantify the costs of the project and construction of the building, respectively $C P_{B}$ and $C C_{B}$, which are the costs incurred during the startup of the investment $C I_{B}$ :

$C I_{B}=C P_{B}+C C_{B}$

The suggested approach considers total costs of building management $\left(C M T_{B}\right)$ on an annual basis, from year 1 to OT, which represents the time horizon. $C M T_{B}$ for a given year $t \in[0, \mathrm{OT}]$ is represented as follows Equation 2:

$C M T_{\mathrm{B}}=C M e_{B}+C M m_{B}+C M o_{B}$

where, $C M e_{B t}$ is the energy cost of the building in a given year $t \in[1, \mathrm{OT}], C M m_{B t}$ is the cost of maintenance 
of the building and $C M o_{B t}$ is other costs of the building, which for a given $t \in[1, \mathrm{OT}]$ is Equation 3:

$$
C M e_{B}=\sum_{e=1}^{E} C m e_{B e}
$$

where, $C m e_{B e}$ is a single item of cost for energy. In addition, we have Equation 4:

$$
C M m_{B}=\sum_{m=1}^{M} C m m_{B m}
$$

where, $\mathrm{Cmm}_{B m}$ is a single item of cost for maintenance. Finally, we have Equation 4:

$$
C M o_{B}=\sum_{o=1}^{O} C m o_{B o}
$$

where, $\mathrm{Cmo}_{B o}$ is a single item of other costs. Thus, the annual cost of management is expressed as the sum of three row vectors, $\mathrm{CMe} 1, \mathrm{E}=<\mathrm{Cme} 1,1 \ldots$ Cme1, $\mathrm{E}>$, $\mathrm{CMm} 1, \mathrm{M}=<\mathrm{Cmm} 1,1 \quad \ldots \mathrm{Cmm1, \textrm {M } >}, \mathrm{CMo} 1, \mathrm{O}=$ $<\mathrm{Cmo1}, 1 \ldots \mathrm{Cmo1}, \mathrm{O}>$, representing the number of individual cost items for the categories of costs for energy (E), maintenance (M) and general cost $(\mathrm{O})$ that have to be calculated $\forall t \in[1, \mathrm{OT}]$. The model of the life cycle can also consider (Artto, 1994) any gain or loss arising from the disposal of the building or its eventual redevelopment as a terminal value Equation 6:

$$
T V_{B}{ }^{O T}=R d_{B}{ }^{O T}-C d_{B}{ }^{O T}
$$

where, $T V_{B}{ }^{O T}$ is the terminal value of the disposal of the building at time horizon OT, $R d_{B}{ }^{O T}$ is the revenue of disposal of the building at time horizon OT and $C d_{B}{ }^{O T}$ is the cost of disposal of the building at time horizon OT. It is then possible to determine the total cost resulting from LCC, discounting values during the entire useful life of the investment as follows:

$$
T C_{B}{ }^{O T}=C I_{B}+\sum_{t=1}^{O T} \frac{C M T_{B t}}{(1+i)^{t}}-\frac{T V_{B}^{O T}}{(1+i)^{o T}}
$$

where, $T C_{B}{ }^{O T}$ is the total discounted cost and $\mathrm{i}$ is the discount rate. In our research, we decided to change the traditional approach of LCC given in Equation 1 by using a different approach based on cash flows, which we call LCF analysis (Iotti and Bonazzi, 2014a) and applying it to the analysis of cash flow analysis, during the entire life cycle of three project alternatives for residential buildings, defined later in the article. We developed the LCF approach because we believe that it can better express the sustainability appraisal of the cycle of the firm's management compared with traditional LCC. The LCF approach would not replace the LCC approach but complement it, particularly in situations relevant to the assessment of financial sustainability. This is particularly true in the case of investments made using debt financing, as frequently occurs in case of real estate investment in buildings for commercial purposes, in addition to private housing investment. In this second case, the financial sustainability evaluation and cash flow absorption analysis are particularly relevant, given the need to quantify debt service cash flow absorption in any given year of the investment, in addition to the entire life cycle. If $D S_{t}$ represents debt service $\forall t \in[1, \mathrm{OT}]$, then $\mathrm{DS}=\mathrm{K}+\mathrm{I}$, where $\mathrm{K}$ is the capital repayment (repayment of debt financing) and $\mathrm{I}$ is the interest payment on debt financing paid in the given year. TV is not considered in the applied model. To complete the applied model, we have to consider the amount of tax benefits $(\mathrm{Tb})$ that the Italian fiscal rules system has issued to incentivize people to invest in renewable energy, which are: (a) Article 16-bis, paragraph 3 of Presidential Decree 917/1986 (Income Tax Act), which provides for a special tax deduction for expenses incurred for the purchase or assignment of property units that are part of a building entirely subject to interventions of restoration and conservation or building renovation conducted by construction or renovation contractors. Paragraph 48 of the Law of Stability 2015 increases the period within which firms (construction companies or restructuring or housing associations) may transfer or assign the housing unit forming part of a restored building to purchaser (final consumer), raising it from 6 to 18 months from the date of the completion of work, with the income tax deduction of $50 \%$ for the maximum spending limit of $€ 96,000$. The basis for the determination of the deduction is made from $25 \%$ of the price reflected by the act of transfer. In the model, we call this incentive "Tb1"; (b) Italian tax legislation allows the person who comes into possession of a first home to detract from income tax the cost of any mortgage. The calculation of the tax savings then serves to determine the reduction that can be achieved in the payment of taxes, deducting from the gross tax amount a part of the interest cost of a loan. The 2008 Finance Act (Law No. 244 of 2007), Article 15, paragraph 1, letter b of the Income Tax Code, limits of the tax credit for the purchase of a first home mortgage increases to $€ 4,000$ form $€ 3,615.20$ previously allowed. Therefore, the maximum income 
tax discount reaches $€ 760$ ( $19 \%$ of $€ 4,000)$, compared with about $€ 687$ (19\% of $€ 3,615.20)$ projected before the 2008 Finance Act. In the model, we call this incentive "Tb2." To achieve $\mathrm{Tb}$, a person must have an income and pay taxes to which, via a tax benefit, a tax payment reduction (deduction) can be applied. In the model, we do not consider a TV of the building, as in Equation 7, because the only-cash-flow approach we have applied does not consider a potential value at the end of the time horizon. We then express Equation 7 using an LCF approach, thus considering DS and Tb1 and $\mathrm{Tb} 2$ as follows:

$$
\begin{aligned}
& T F_{B}{ }^{O T}=F I_{B}+\sum_{t=1}^{O T} \frac{F M T_{B t}}{(1+i)^{t}}+ \\
& +\sum_{t=1}^{O T} \frac{D S_{B t}}{(1+i)^{t}}-\sum_{t=1}^{O T} \frac{T b 1_{t}}{(1+i)^{t}}-\sum_{t=1}^{O T} \frac{T b 2_{t}}{(1+i)^{t}}
\end{aligned}
$$

In Equation 8, the total amount of cash flow $T F_{B}{ }^{O T}$ is given by the total outflow for the initial investment $\left(F I_{B}=F P_{B}+F C_{B}\right)$, where $F P_{B}$ and $F C_{B}$ are the cash outflow for the project and construction of the building, respectively; the total yearly outflow for building management $\forall t \in[1, \mathrm{OT}]$ is $F M T_{B}=F M e_{B}+$ $F M m_{B}+F M o_{B}$, that are, respectively, outflow for energy payment, for maintenance payment and for others cost payment. This total amount of financial outflow is increased by DS in any given year and reduced by $\mathrm{Tb} 1$ and $\mathrm{Tb} 2$ where applicable. Tax benefit is given to consumers for the effects on public goods production of sustainable construction techniques (Tb1) and to help less rich consumers buy their first house for residential purposes (and only for this), as in $\mathrm{Tb} 2$. We have to remember that the environmental effects of construction techniques could be considered as a public good because they produce a share of goods and services characterized by absolute non-rivality and non-excludability in consumption. The reduced emissions of pollutants and energy-saving services are defined as externalities because they are freely accessible and do not pass through market mechanisms. The evaluation of externalities is particularly important in situations where the state intervenes with public spending, as expressed in Equation 8, considering $\mathrm{Tb} 1$ and $\mathrm{Tb} 2$ during time in the model. Model specification is useful to ensure that public resources use is efficient given positive externalities thus ensuring efficient use of public resources. To consider the time effect of monetary values, all financial flows are discounted using a discount rate, $i$, that is the same to discount all flow values. This hypothesis could be relaxed in further applications of the model, for example, by considering the weighted average cost of capital approach, thus considering the different financial fund strategies (full debt, full equity or mixed source approach) that are applied to finance the investment. In any case, for the full debt strategy, we do not have any $F I_{B}$ that are fully debt financed. Moreover, in the case of the full equity approach, we do not have any $F I_{B}$ that are fully equity financed, without interest charges to be considered in a tax reduction via tax a deduction. The formulation given by Equation 8 could be applied to calculate the average cash outflow per unit time, generally yearly, $\left(T F_{y}\right)$ as follows Equation 9:

$T F_{y}=\frac{T F_{B}^{O T}}{O T}$

The LCF approach could then be useful for comparing alternative building strategies investment, even for private housing investment, by comparing different $\mathrm{TF}_{\mathrm{y}}$ of different property investment options and then choosing, ceteris paribus, the investment characterized by the smallest $\mathrm{TF}_{\mathrm{y}}$ (in this case, considering only the objective to minimize the cash outflow amount while choosing a property investment). In the method, it could be useful to define a metric to quantify cash flow absorption per year and per unit surface, typically a square meter of horizontal surface of the building. The expression is:

$T F_{y}^{s u}=\frac{T F_{y}}{s u}$

In Equation 10, $T F_{y}{ }^{s u}$ is the average cash outflow per unit time (that is, year y) and per surface unit (su); typically $T F_{y}^{s u}$ expresses the cash outflow per year and per square meter of surface of the building. Using $T F_{y}{ }^{s u}$, it is possible to compare different investments in buildings, even if characterized by different time horizons and different surfaces; it is, in any case, to consider that are properly comparable investment in building characterized by similar functional vocation. By applying Equation 10, the LCF approach is applied to compare alternative building strategies investment, including private housing investment, comparing different property investment options and then choosing, ceteris paribus, the investment characterized by the smallest $T F_{y}{ }^{s u}$. The method has some limitations that could be overcome in subsequent research and/or well specified in their effects on the model results, in every application, particularly regarding the following: (1) The method does not consider terminal values as cash inflow in decreasing cash outflow amount, which could be different for different types of construction technologies, particularly if characterized by different 
time horizons; (2) the discount rate applied to the different type of cash outflow could differ, perhaps significantly and depend on general trends in the economy, such as inflation and country risk during time and differ given the financial risk of the different financial structures of the investor, for example, public and/or private, not considered in the model. It is necessary to be clear for every application whether the discount rate is "real" or "nominal", thus not considering inflation dynamics; (3) different technologies may have different lengths of construction phase, in which case, it could be useful to compare different level of financial charge, explicit or implicit, for the different technology choices.

\section{Results}

The methods used to encourage the production of electricity from renewable sources (excluding photovoltaic systems) were established in Italy by the Decree of the Ministry (DM) on July 6, 2012. The proposed LCF model was applied to assess the total cash flow $\left(T F_{B}{ }^{O T}\right)$, cash flow per year $\left(T F_{y}\right)$ and cash flow per year and per surface unit in square meters $\left(T F_{y}^{s u}\right)$, for two alternative house building projects. The projects involve a single family house located in the municipality of Berceto in the province of Parma in northern Italy at an altitude of 850 meters above sea level. The property is built on a plot with a smooth surface of about 1,500 square meters and has an area of 150 square meters on the plan. The house has two floors: A ground floor and first floor, with a total height from ground level of 8 meters. The space under the roof is not habitable. The building was built from scratch on a previous building complex that collapsed following neglect by the previous owners. The application of the model provides for the evaluation of two project alternatives for three scenarios: A (case 1), B.1 (case 2) and B.2 (case 3). Project A involves construction using "wet" technologies, curtain walls in brick and a reinforced concrete structure. Alternative B envisages the construction using "dry" technologies, with a wooden structure and "dry" curtain walls. For alternative B there is case B.1 (case 2) without tax incentives (Tb1) for sustainable construction and case B.2 (case 3) with tax incentives (Tb1) for sustainable building. The first tax benefit (Tb1) is calculated according to the Italian rules on tax incentives for sustainable construction, accounting for $12.50 \%$ of the construction cost $(50 \%$ of $25 \%$ ), to be deducted from the tax payment in 10 years. All project alternatives have the option of full debt, with the full cost of the property covered by a bank loan secured by a mortgage, with a 20 -year, fixed rate of $2.50 \%$ on an annual basis. As a result of the full assumption of debt, the discount rate for all values has been quantified at $2.50 \%$, which is the cost of the financial debt that is hypothetically the annual cost to finance the purchase of the property. In future research, there will be cases involving mixed financing, with debt and equity and the consideration of a Weighted Average Cost of Capital (WACC) approach. The tax advantage Tb2 is then calculated for all three project, given the full debt financing hypothesis. Management cost are inflated on the basis of long-term forecasts, with a $1.00 \%$ constant inflation rate. The time horizon is 20 years, which is equal to the duration of the mortgage. A terminal value of the property is not expected, according to the purpose of research, which is aimed at quantifying the absorption of resources and not value creation, as terminal value is.

Table 1 analyzes the outflows related to the construction costs of the building and the project. According to the hypothesis, it does not consider the cost of land (which is the same for each project) and the implicit cost of use of capital in the construction phase. For each project alternative, we assume that full financial coverage and, therefore, the values in Table 1 do not involve an immediate financial output, but a gradual repayment with debt servicing, as indicated in Table 6 . The total investment is $€ 341,430$ for project $A$ and $€ 310,380$ for project B (B.1 and B.2 have the same initial cost, differing only in the application of tax incentive Tb1 in B.2). The two classes of projects, A and $\mathrm{B}$, differ because the useful surface of $\mathrm{B}$ is greater than the surface of A (289 and 267 square meters, respectively). This difference is due to the different technology used in "dry" wall construction, which allows the use of thinner interior walls and consequently increases the useful walk able surface. The initial investment is $€ 1,279$ per square meter for project $A$ and $€ 1,074$ for project $B$. The analysis of the absorption of resources for energy is shown in Table 2. The cost of heating and cooling for project $\mathrm{A}$ is $€ 2,200$, while project $B$ has annual charges of $€ 800$ (all inflated at an annual rate of $1.00 \%$ and discounted at a rate of $2.50 \%$ yearly rate. The energy of sustainable technology applied in project $\mathrm{B}$ allows an energy cost saving of $€ 1,400$ per year. The annual cash outflow is $€ 1,891$ per year for project $A$ and $€ 688$ per year for project $\mathrm{B}$. The cash outflow is $€ 7.08$ per square meter for project $A$ and $€ 2.38$ for project B. The analysis of the absorption of resources for maintenance is shown in Table 3 . The sustainable technology applied in project $B$, as a result of better access to facilities to be repaired due to the modularity of coverage and because there is no 
requirement for breaks during maintenance, allows estimated savings of $€ 502$ per year on maintenance outflow. The annual cash outflow is $€ 1,274$ per year for project $A$ and $€ 772$ per year for project $B$. The cash outflow is $€ 4.77$ per square meter for project $A$ and $€ 2.77$ for project $B$.

Table 1. Financial outflow of the building in the construction phase (FI)

\begin{tabular}{|c|c|c|c|c|}
\hline \multirow[b]{2}{*}{ Financial outflow of the building in the construction phase } & \multirow[b]{2}{*}{$\begin{array}{l}\text { Type of } \\
\text { outflow }\end{array}$} & \multicolumn{3}{|c|}{ Value in $€$ - Year 0 -construction phase } \\
\hline & & $\begin{array}{l}\text { Building } \\
\text { A-Case } 1 \\
\end{array}$ & $\begin{array}{l}\text { Building } \\
\text { B.1-Case } 2\end{array}$ & $\begin{array}{l}\text { Building } \\
\text { B.2-Case } 3 \\
\end{array}$ \\
\hline Project & FP & 12500 & 8000 & 8000 \\
\hline Waterproofing, drainage and insulation & FC & 12350 & 11800 & 11800 \\
\hline Covers & FC & 32560 & 32560 & 32560 \\
\hline Finishes & FC & 15500 & 15500 & 15500 \\
\hline Installations & $\mathrm{FC}$ & 41220 & 38120 & 38120 \\
\hline Windows, doors, railings, windows and eaves & FC & 36550 & 36550 & 36550 \\
\hline Horizontal walls, foundations and floors & FC & 38210 & 32160 & 32160 \\
\hline Vertical walls & $\mathrm{FC}$ & 41660 & 38200 & 38200 \\
\hline Flooring, paneling and paintings & FC & 24550 & 24550 & 24550 \\
\hline Scaffoldings & FC & 3660 & 2100 & 2100 \\
\hline Interior and exterior doors & FC & 11600 & 11600 & 11600 \\
\hline Stairs and balconies & $\mathrm{FC}$ & 14650 & 14650 & 14650 \\
\hline Excavations and foundations & $\mathrm{FC}$ & 21500 & 15600 & 15600 \\
\hline Structures & FC & 34920 & 28980 & 28980 \\
\hline Total investment & FI & 341430 & 310370 & 310370 \\
\hline Square meters $\mathrm{m}^{2}$ (available per housing) & & 267 & 289 & 289 \\
\hline Financial outflow per square meters & & 1279 & 1074 & 1074 \\
\hline
\end{tabular}

Source: Our processing of directly collected data

Table 2. Financial outflow for energy in the management phase

\begin{tabular}{|c|c|c|c|c|}
\hline \multirow{2}{*}{$\begin{array}{l}\text { Financial outflow for energy } \\
\text { FFe per year } \\
\text { (inflation rate } 1,0 \% \text {-discount rate } 2,5 \% \text { ) }\end{array}$} & \multirow[b]{2}{*}{$\begin{array}{l}\text { Type of } \\
\text { outflow }\end{array}$} & \multicolumn{3}{|c|}{ Value in $€$ - Year $1 / 20$-management phase } \\
\hline & & $\begin{array}{l}\text { Building } \\
\text { A-Case } 1 \\
\end{array}$ & $\begin{array}{l}\text { Building } \\
\text { B.1-Case 2 } \\
\end{array}$ & $\begin{array}{l}\text { Building } \\
\text { B.2-Case } 3\end{array}$ \\
\hline FMe year 1 & $\mathrm{FMe}$ & 2168.00 & 788.00 & 788.00 \\
\hline FMe year 2 & $\mathrm{FMe}$ & 2136.00 & 777.00 & 777.00 \\
\hline FMe year 3 & $\mathrm{FMe}$ & 2105.00 & 765.00 & 765.00 \\
\hline FMe year 4 & $\mathrm{FMe}$ & 2074.00 & 754.00 & 754.00 \\
\hline FMe year 5 & $\mathrm{FMe}$ & 2044.00 & 743.00 & 743.00 \\
\hline FMe year 6 & $\mathrm{FMe}$ & 2014.00 & 732.00 & 732.00 \\
\hline FMe year 7 & $\mathrm{FMe}$ & 1984.00 & 722.00 & 722.00 \\
\hline FMe year 8 & $\mathrm{FMe}$ & 1955.00 & 711.00 & 711.00 \\
\hline FMe year 9 & FMe & 1927.00 & 701.00 & 701.00 \\
\hline FMe year 10 & $\mathrm{FMe}$ & 1898.00 & 690.00 & 690.00 \\
\hline FMe year 11 & $\mathrm{FMe}$ & 1871.00 & 680.00 & 680.00 \\
\hline FMe year 12 & $\mathrm{FMe}$ & 1843.00 & 670.00 & 670.00 \\
\hline FMe year 13 & $\mathrm{FMe}$ & 1816.00 & 660.00 & 660.00 \\
\hline FMe year 14 & $\mathrm{FMe}$ & 1790.00 & 651.00 & 651.00 \\
\hline FMe year 15 & $\mathrm{FMe}$ & 1764.00 & 641.00 & 641.00 \\
\hline FMe year 16 & FMe & 1738.00 & 632.00 & 632.00 \\
\hline FMe year 17 & $\mathrm{FMe}$ & 1712.00 & 623.00 & 623.00 \\
\hline FMe year 18 & $\mathrm{FMe}$ & 1687.00 & 614.00 & 614.00 \\
\hline FMe year 19 & $\mathrm{FMe}$ & 1663.00 & 605.00 & 605.00 \\
\hline FMe year 20 & $\mathrm{FMe}$ & 1638.00 & 596.00 & 596.00 \\
\hline Total FMe financial outflow & $\mathrm{FMe}$ & 37826.00 & 13755.00 & 13755.00 \\
\hline Financial outflow per year & & 1891.00 & 688.00 & 688.00 \\
\hline Square meters $\mathrm{m}^{2}$ (available per housing) & & 267.00 & 289.00 & 289.00 \\
\hline Financial outflow per square meters per year & & 7.08 & 2.38 & 2.38 \\
\hline
\end{tabular}

Source: Our processing of directly collected data 
Table 3. Financial outflow for maintenance in the management phase

\begin{tabular}{|c|c|c|c|c|}
\hline \multirow[b]{2}{*}{$\begin{array}{l}\text { Financial outflow for maintenance } \\
\text { FFm per year } \\
\text { (inflation rate } 1,0 \% \text {-discount rate } 2,5 \% \text { ) }\end{array}$} & \multirow[b]{2}{*}{$\begin{array}{l}\text { Type of } \\
\text { outflow }\end{array}$} & \multicolumn{3}{|c|}{ Value in $€$ - Year $1 / 20$-management phase } \\
\hline & & $\begin{array}{l}\text { Building } \\
\text { A-Case } 1\end{array}$ & $\begin{array}{l}\text { Building } \\
\text { B.1-Case 2 }\end{array}$ & $\begin{array}{l}\text { Building } \\
\text { B.2-Case } 3\end{array}$ \\
\hline FMm year 1 & FMm & 0.00 & 0.00 & 0.00 \\
\hline FMm year 2 & FMm & 388.00 & 243.00 & 243.00 \\
\hline FMm year 3 & FMm & 383.00 & 239.00 & 239.00 \\
\hline FMm year 4 & FMm & 377.00 & 236.00 & 236.00 \\
\hline FMm year 5 & FMm & 929.00 & 464.00 & 464.00 \\
\hline FMm year 6 & FMm & 549.00 & 275.00 & 275.00 \\
\hline FMm year 7 & FMm & 541.00 & 271.00 & 271.00 \\
\hline FMm year 8 & FMm & 533.00 & 267.00 & 267.00 \\
\hline FMm year 9 & FMm & 525.00 & 263.00 & 263.00 \\
\hline FMm year 10 & FMm & 12944.00 & 8629.00 & 8629.00 \\
\hline FMm year 11 & FMm & 510.00 & 255.00 & 255.00 \\
\hline FMm year 12 & FMm & 503.00 & 251.00 & 251.00 \\
\hline FMm year 13 & FMm & 495.00 & 248.00 & 248.00 \\
\hline FMm year 14 & FMm & 488.00 & 244.00 & 244.00 \\
\hline FMm year 15 & FMm & 4008.00 & 2405.00 & 2405.00 \\
\hline FMm year 16 & FMm & 474.00 & 237.00 & 237.00 \\
\hline FMm year 17 & FMm & 467.00 & 233.00 & 233.00 \\
\hline FMm year 18 & FMm & 460.00 & 230.00 & 230.00 \\
\hline FMm year 19 & FMm & 453.00 & 227.00 & 227.00 \\
\hline FMm year 20 & FMm & 447.00 & 223.00 & 223.00 \\
\hline Total FMm financial outflow & FMm & 25476.00 & 15440.00 & 15440.00 \\
\hline Financial outflow per year & & 1274.00 & 772.00 & 772.00 \\
\hline Square meters $\mathrm{m}^{2}$ (available per housing) & & 267.00 & 289.00 & 289.00 \\
\hline Financial outflow per square meters per year & & 4.77 & 2.67 & 2.67 \\
\hline
\end{tabular}

Source: Our processing of directly collected data

Table 4. Financial outflow for other voices of cost in the management phase

\begin{tabular}{|c|c|c|c|c|}
\hline \multirow{2}{*}{$\begin{array}{l}\text { Financial outflow for other voices of cost } \\
\text { FFo per year } \\
\text { (inflation rate } 1,0 \% \text {-discount rate } 2,5 \% \text { ) }\end{array}$} & \multirow[b]{2}{*}{$\begin{array}{l}\text { Type of } \\
\text { outflow }\end{array}$} & \multicolumn{3}{|c|}{ Value in $€$-Year $1 / 20$-management phase } \\
\hline & & $\begin{array}{l}\text { Building } \\
\text { A-Case } 1\end{array}$ & $\begin{array}{l}\text { Building } \\
\text { B.1-Case } 2\end{array}$ & $\begin{array}{l}\text { Building } \\
\text { B.2-Case } 3\end{array}$ \\
\hline FMo year 1 & FMo & 0.00 & 0.00 & 0.00 \\
\hline FMo year 2 & FMo & 194.00 & 194.00 & 194.00 \\
\hline FMo year 3 & FMo & 191.00 & 191.00 & 191.00 \\
\hline FMo year 4 & FMo & 189.00 & 189.00 & 189.00 \\
\hline FMo year 5 & FMo & 186.00 & 186.00 & 186.00 \\
\hline FMo year 6 & FMo & 183.00 & 183.00 & 183.00 \\
\hline FMo year 7 & FMo & 180.00 & 180.00 & 180.00 \\
\hline FMo year 8 & FMo & 178.00 & 178.00 & 178.00 \\
\hline FMo year 9 & FMo & 175.00 & 175.00 & 175.00 \\
\hline FMo year 10 & FMo & 173.00 & 173.00 & 173.00 \\
\hline FMo year 11 & FMo & 170.00 & 170.00 & 170.00 \\
\hline FMo year 12 & FMo & 168.00 & 168.00 & 168.00 \\
\hline FMo year 13 & FMo & 165.00 & 165.00 & 165.00 \\
\hline FMo year 14 & FMo & 163.00 & 163.00 & 163.00 \\
\hline FMo year 15 & FMo & 160.00 & 160.00 & 160.00 \\
\hline FMo year 16 & FMo & 158.00 & 158.00 & 158.00 \\
\hline FMo year 17 & FMo & 156.00 & 156.00 & 156.00 \\
\hline FMo year 18 & FMo & 153.00 & 153.00 & 153.00 \\
\hline FMo year 19 & FMo & 151.00 & 151.00 & 151.00 \\
\hline FMo year 20 & FMo & 149.00 & 149.00 & 149.00 \\
\hline Total FMo financial outflow & FMo & 3242.00 & 3242.00 & 3242.00 \\
\hline Financial outflow per year & & 162.00 & 162.00 & 162.00 \\
\hline Square meters $\mathrm{m}^{2}$ (available per housing) & & 267.00 & 289.00 & 289.00 \\
\hline Financial outflow per square meters per year & & 0.61 & 0.56 & 0.56 \\
\hline
\end{tabular}

Source: Our processing of directly collected data 
The analysis of the absorption of resources for other costs is shown in Table 4. The result of the absorption of resources is equal for both projects $\mathrm{A}$ and $\mathrm{B}$ and the cash outflow per year is $€ 162$ for each project. Given the difference in the walkable surface, the cash outflow for other costs is $€ 0.61$ per square meter for project $A$ and $€ 0.56$ for project $\mathrm{B}$.

The analysis of the absorption of resources for operating expenses is shown in Table 5. Total expenses for the management of the building in project $A$ is $€ 66,544$, while project $\mathrm{B}$ has a total charge of $€ 32,436$. The sustainable technology applied in project B allows for a saving of $€ 1,705$ per year on the cost of building management. The annual cash outflow is $€ 3,327$ per year for project $A$ and $€ 1,622$ per year for project $B$. The cash outflow is $€ 12.46$ per square meter for project $\mathrm{A}$ and $€ 5.61$ for project $\mathrm{B}$. Table 6 shows the cash outflows due to repayment of debt for paying the construction costs of the building and the project. The total investment is $€ 341,430$ for project $A$ and $€ 310,380$ for project $B$. The financial loan has a duration of 20 years and the interest rate cost is $2.50 \%$ on an annual basis. This cost is canceled as a result of discounting at a rate equal to the interest rate of the given loan according to the hypothesis of financing full debt with a financed debt. In the model, for simplicity, we do not consider the transaction costs of the loan that, in any case, would be equal in the three cases considered (or slightly divergent as a percentage of the value). Given the differences in the cost of construction for the projects and given the different usable surface, the two projects will have different results of cash outflow. The sustainable technology applied in project B allows a saving of $€ 31,060$ on building costs to be reimbursed by the DS. The cash outflow per year is $€ 17$ for project $A$ and $€ 15,519$ per year for project $B$. The DS of B with respect to A is $90.90 \%$ (savings of $9.10 \%)$, but because of the greater useful walkable surface of B compared to A, these savings increase to $16.02 \%$ in terms of cost per square meter of surface per year. The cash outflow is $€ 63.94$ per square meter for project $A$ and $€ 53.70$ for project $B$. Tb1 tax benefit analysis is performed in Table 7 . Tb1 is calculated as a deduction of $12.50 \%$ from the construction cost $(50 \%$ of $25 \%$ ), to be detracted from the tax payment in 10 years, as the total amount of $€ 38,796$ not discounted. $\mathrm{Tb} 1$ is calculated only for project B, case B. 2 and has a total amount, after reducing financial outflow for consumers, of $€ 33,955$. The financial inflow then decreasing TFy is $€ 1,698$ per year, that is, $€ 5.87$ per square meter per year in case B.2. Tb2 tax benefit analysis is performed in Table 8 . Tb1 is calculated as a deduction of $19.00 \%$ of the interest on the financial debt, with a maximum of $€ 4,000$ per year. Thus, the maximum amount of $\mathrm{Tb} 2$ is $€ 760$ per year, that is, $19.00 \%$ of $€ 4,000$.

Table 5. Financial outflow for total management

\begin{tabular}{|c|c|c|c|c|}
\hline \multirow{2}{*}{$\begin{array}{l}\text { Financial outflow for total management } \\
\text { FMT per year } \\
\text { (inflation rate } 1,0 \% \text {-discount rate } 2,5 \% \text { ) }\end{array}$} & \multirow[b]{2}{*}{$\begin{array}{l}\text { Type of } \\
\text { outflow }\end{array}$} & \multicolumn{3}{|c|}{ Value in $€$ - Year 1/20 -management phase } \\
\hline & & $\begin{array}{l}\text { Building } \\
\text { A-Case } 1 \\
\end{array}$ & $\begin{array}{l}\text { Building } \\
\text { B.1-Case 2 }\end{array}$ & $\begin{array}{l}\text { Building } \\
\text { B.2-Case } 3 \\
\end{array}$ \\
\hline FMT year 1 & FMT & 2168.00 & 788.00 & 788.00 \\
\hline FMT year 2 & FMT & 2719.00 & 1214.00 & 1214.00 \\
\hline FMT year 3 & FMT & 2679.00 & 1196.00 & 1196.00 \\
\hline FMT year 4 & FMT & 2640.00 & 1178.00 & 1178.00 \\
\hline FMT year 5 & FMT & 3158.00 & 1393.00 & 1393.00 \\
\hline FMT year 6 & FMT & 2746.00 & 1190.00 & 1190.00 \\
\hline FMT year 7 & FMT & 2706.00 & 1173.00 & 1173.00 \\
\hline FMT year 8 & FMT & 2666.00 & 1155.00 & 1155.00 \\
\hline FMT year 9 & FMT & 2627.00 & 1138.00 & 1138.00 \\
\hline FMT year 10 & FMT & 15015.00 & 9492.00 & 9492.00 \\
\hline FMT year 11 & FMT & 2551.00 & 1105.00 & 1105.00 \\
\hline FMT year 12 & FMT & 2514.00 & 1089.00 & 1089.00 \\
\hline FMT year 13 & FMT & 2477.00 & 1073.00 & 1073.00 \\
\hline FMT year 14 & FMT & 2441.00 & 1058.00 & 1058.00 \\
\hline FMT year 15 & FMT & 5932.00 & 3206.00 & 3206.00 \\
\hline FMT year 16 & FMT & 2370.00 & 1027.00 & 1027.00 \\
\hline FMT year 17 & FMT & 2335.00 & 1012.00 & 1012.00 \\
\hline FMT year 18 & FMT & 2301.00 & 997.00 & 997.00 \\
\hline FMT year 19 & FMT & 2267.00 & 982.00 & 982.00 \\
\hline FMT year 20 & FMT & 2234.00 & 968.00 & 968.00 \\
\hline Total FMT financial outflow & FMT & 66544.00 & 32436.00 & 32436.00 \\
\hline Financial outflow per year & & 3327.00 & 1622.00 & 1622.00 \\
\hline Square meters $\mathrm{m}^{2}$ (available per housing) & & 267.00 & 289.00 & 289.00 \\
\hline Financial outflow per square meters per year & & 12.46 & 5.61 & 5.61 \\
\hline
\end{tabular}

Source: Our processing of directly collected data 
Table 6. Debt service financial outflow

\begin{tabular}{|c|c|c|c|c|}
\hline \multirow{2}{*}{$\begin{array}{l}\text { Debt Service Financial outflow } \\
\text { DS per year } \\
\text { (debt pricing } 2,5 \% \text { - discount rate } 2,5 \% \text { ) }\end{array}$} & \multirow[b]{2}{*}{$\begin{array}{l}\text { Type of } \\
\text { outflow }\end{array}$} & \multicolumn{3}{|c|}{ Value in $€$ - Year 1/20 -debt service } \\
\hline & & $\begin{array}{l}\text { Building } \\
\text { A-Case } 1\end{array}$ & $\begin{array}{l}\text { Building } \\
\text { B.1-Case 2 }\end{array}$ & $\begin{array}{l}\text { Building } \\
\text { B.2-Case } 3\end{array}$ \\
\hline DS year 1 & DS & 21368.00 & 19424.00 & 19424.00 \\
\hline DS year 2 & DS & 20846.00 & 18950.00 & 18950.00 \\
\hline DS year 3 & DS & 20338.00 & 18488.00 & 18488.00 \\
\hline DS year 4 & DS & 19842.00 & 18037.00 & 18037.00 \\
\hline DS year 5 & DS & 19358.00 & 17597.00 & 17597.00 \\
\hline DS year 6 & DS & 18886.00 & 17168.00 & 17168.00 \\
\hline DS year 7 & DS & 18425.00 & 16749.00 & 16749.00 \\
\hline DS year 8 & DS & 17976.00 & 16341.00 & 16341.00 \\
\hline DS year 9 & DS & 17537.00 & 15942.00 & 15942.00 \\
\hline DS year 10 & DS & 17110.00 & 15553.00 & 15553.00 \\
\hline DS year 11 & DS & 16692.00 & 15174.00 & 15174.00 \\
\hline DS year 12 & DS & 16285.00 & 14804.00 & 14804.00 \\
\hline DS year 13 & DS & 15888.00 & 14443.00 & 14443.00 \\
\hline DS year 14 & DS & 15500.00 & 14090.00 & 14090.00 \\
\hline DS year 15 & DS & 15122.00 & 13747.00 & 13747.00 \\
\hline DS year 16 & DS & 14754.00 & 13411.00 & 13411.00 \\
\hline DS year 17 & DS & 14394.00 & 13084.00 & 13084.00 \\
\hline DS year 18 & DS & 14043.00 & 12765.00 & 12765.00 \\
\hline DS year 19 & DS & 13700.00 & 12454.00 & 12454.00 \\
\hline DS year 20 & DS & 13366.00 & 12150.00 & 12150.00 \\
\hline Total DS financial outflow & DS & 341430.00 & 310370.00 & 310370.00 \\
\hline Financial outflow per year & & 17072.00 & 15519.00 & 15519.00 \\
\hline Square meters $\mathrm{m}^{2}$ (available per housing) & & 267.00 & 289.00 & 289.00 \\
\hline Financial outflow per square meters per year & & 63.94 & 53.70 & 53.70 \\
\hline
\end{tabular}

Source: Our processing of directly collected data

Table 7. Tb1 Financial inflow

\begin{tabular}{|c|c|c|c|c|}
\hline \multirow{2}{*}{$\begin{array}{l}\text { Tb1 Financial inflow } \\
\text { Tb1 per year } \\
\text { (discount rate } 2,5 \% \text { ) }\end{array}$} & \multirow[b]{2}{*}{$\begin{array}{l}\text { Type of } \\
\text { inflow }\end{array}$} & \multicolumn{3}{|c|}{ Value in $€$ - Year 1/20 -tax benefit } \\
\hline & & $\begin{array}{l}\text { Building } \\
\text { A-Case } 1\end{array}$ & $\begin{array}{l}\text { Building } \\
\text { B.1-Case } 2\end{array}$ & $\begin{array}{l}\text { Building } \\
\text { B.2-Case } 3\end{array}$ \\
\hline Tb1 year 1 & Tb1 & 0.00 & 0.00 & 3785.00 \\
\hline Tb1 year 2 & $\mathrm{~Tb} 1$ & 0.00 & 0.00 & 3693.00 \\
\hline Tb1 year 3 & $\mathrm{~Tb} 1$ & 0.00 & 0.00 & 3603.00 \\
\hline Tb1 year 4 & $\mathrm{~Tb} 1$ & 0.00 & 0.00 & 3515.00 \\
\hline $\mathrm{Tb} 1$ year 5 & $\mathrm{~Tb} 1$ & 0.00 & 0.00 & 3429.00 \\
\hline $\mathrm{Tb} 1$ year 6 & $\mathrm{~Tb} 1$ & 0.00 & 0.00 & 3345.00 \\
\hline Tb1 year 7 & $\mathrm{~Tb} 1$ & 0.00 & 0.00 & 3264.00 \\
\hline Tb1 year 8 & $\mathrm{~Tb} 1$ & 0.00 & 0.00 & 3184.00 \\
\hline Tb1 year 9 & $\mathrm{~Tb} 1$ & 0.00 & 0.00 & 3107.00 \\
\hline Tb1 year 10 & $\mathrm{~Tb} 1$ & 0.00 & 0.00 & 3031.00 \\
\hline Tb1 year 11 & $\mathrm{~Tb} 1$ & 0.00 & 0.00 & 0.00 \\
\hline Tb1 year 12 & $\mathrm{~Tb} 1$ & 0.00 & 0.00 & 0.00 \\
\hline Tb1 year 13 & $\mathrm{~Tb} 1$ & 0.00 & 0.00 & 0.00 \\
\hline Tb1 year 14 & $\mathrm{~Tb} 1$ & 0.00 & 0.00 & 0.00 \\
\hline Tb1 year 15 & $\mathrm{~Tb} 1$ & 0.00 & 0.00 & 0.00 \\
\hline Tb1 year 16 & $\mathrm{~Tb} 1$ & 0.00 & 0.00 & 0.00 \\
\hline Tb1 year 17 & $\mathrm{~Tb} 1$ & 0.00 & 0.00 & 0.00 \\
\hline Tb1 year 18 & $\mathrm{~Tb} 1$ & 0.00 & 0.00 & 0.00 \\
\hline Tb1 year 19 & $\mathrm{~Tb} 1$ & 0.00 & 0.00 & 0.00 \\
\hline Tb1 year 20 & $\mathrm{~Tb} 1$ & 0.00 & 0.00 & 0.00 \\
\hline Total Tb1 financial inflow & $\mathrm{Tb} 1$ & 0.00 & 0.00 & 33955.00 \\
\hline Financial inflow per year & & 0.00 & 0.00 & 1698.00 \\
\hline Square meters $\mathrm{m}^{2}$ (available per housing) & & 267.00 & 289.00 & 289.00 \\
\hline Financial inflow per square meters per year & & 0.00 & 0.00 & 5.87 \\
\hline
\end{tabular}

Source: Our processing of directly collected data 
Table 8. Tb2 Financial inflow

\begin{tabular}{|c|c|c|c|c|}
\hline \multirow{2}{*}{$\begin{array}{l}\text { Tb2 Financial inflow } \\
\text { Tb2 per year } \\
\text { (debt pricing } 2,5 \% \text {-discount rate } 2,5 \% \text { ) }\end{array}$} & \multirow[b]{2}{*}{$\begin{array}{l}\text { Type of } \\
\text { inflow }\end{array}$} & \multicolumn{3}{|c|}{ Value in $€$ - Year 1/ 20 - tax benefit } \\
\hline & & $\begin{array}{l}\text { Building } \\
\text { A-Case } 1\end{array}$ & $\begin{array}{l}\text { Building } \\
\text { B.1-Case 2 }\end{array}$ & $\begin{array}{l}\text { Building } \\
\text { B.2-Case } 3\end{array}$ \\
\hline $\mathrm{Tb} 2$ year 1 & $\mathrm{~Tb} 2$ & 741.00 & 741.00 & 741.00 \\
\hline $\mathrm{Tb} 2$ year 2 & $\mathrm{~Tb} 2$ & 723.00 & 723.00 & 723.00 \\
\hline $\mathrm{Tb} 2$ year 3 & $\mathrm{~Tb} 2$ & 706.00 & 706.00 & 706.00 \\
\hline Tb2 year 4 & $\mathrm{~Tb} 2$ & 689.00 & 689.00 & 689.00 \\
\hline Tb2 year 5 & $\mathrm{~Tb} 2$ & 672.00 & 672.00 & 672.00 \\
\hline Tb2 year 6 & $\mathrm{~Tb} 2$ & 655.00 & 655.00 & 655.00 \\
\hline Tb2 year 7 & $\mathrm{~Tb} 2$ & 639.00 & 639.00 & 639.00 \\
\hline Tb2 year 8 & $\mathrm{~Tb} 2$ & 624.00 & 624.00 & 624.00 \\
\hline Tb2 year 9 & $\mathrm{~Tb} 2$ & 609.00 & 609.00 & 609.00 \\
\hline $\mathrm{Tb} 2$ year 10 & $\mathrm{~Tb} 2$ & 594.00 & 594.00 & 594.00 \\
\hline $\mathrm{Tb} 2$ year 11 & $\mathrm{~Tb} 2$ & 579.00 & 579.00 & 579.00 \\
\hline $\mathrm{Tb} 2$ year 12 & $\mathrm{~Tb} 2$ & 565.00 & 560.00 & 560.00 \\
\hline $\mathrm{Tb} 2$ year 13 & $\mathrm{~Tb} 2$ & 541.00 & 492.00 & 492.00 \\
\hline $\mathrm{Tb} 2$ year 14 & $\mathrm{~Tb} 2$ & 467.00 & 425.00 & 425.00 \\
\hline $\mathrm{Tb} 2$ year 15 & $\mathrm{~Tb} 2$ & 396.00 & 360.00 & 360.00 \\
\hline $\mathrm{Tb} 2$ year 16 & $\mathrm{~Tb} 2$ & 326.00 & 296.00 & 296.00 \\
\hline $\mathrm{Tb} 2$ year 17 & $\mathrm{~Tb} 2$ & 257.00 & 234.00 & 234.00 \\
\hline $\mathrm{Tb} 2$ year 18 & $\mathrm{~Tb} 2$ & 191.00 & 173.00 & 173.00 \\
\hline Tb2 year 19 & $\mathrm{~Tb} 2$ & 125.00 & 114.00 & 114.00 \\
\hline $\mathrm{Tb} 2$ year 20 & $\mathrm{~Tb} 2$ & 62.00 & 56.00 & 56.00 \\
\hline Total $\mathrm{Tb} 2$ financial inflow & $\mathrm{Tb} 2$ & 10161.00 & 9941.00 & 9941.00 \\
\hline Financial inflow per year & & 508.00 & 497.00 & 497.00 \\
\hline Square meters $\mathrm{m}^{\frac{1}{2}}$ (available per housing) & & 267.00 & 289.00 & 289.00 \\
\hline Financial inflow per square meters per year & & 1.90 & 1.72 & 1.72 \\
\hline
\end{tabular}

Source: Our processing of directly collected data

Table 9. $T F_{B}{ }^{O T}$ Financial results

\begin{tabular}{|c|c|c|c|c|}
\hline \multirow[b]{2}{*}{$\begin{array}{l}\mathrm{TF}_{\mathrm{B}}^{\mathrm{OT}} \text { Financial results } \\
\mathrm{TF} \text { per year } \\
\text { (debt pricing 2,5\% -discount rate 2,5\%) }\end{array}$} & \multirow[b]{2}{*}{$\begin{array}{l}\text { Type of } \\
\text { flow }\end{array}$} & \multicolumn{3}{|c|}{ Value in $€-$ Year 1/ 20 -LCF financial results } \\
\hline & & $\begin{array}{l}\text { Building } \\
\text { A-Case } 1\end{array}$ & $\begin{array}{l}\text { Building } \\
\text { B.1-Case } 2\end{array}$ & $\begin{array}{l}\text { Building } \\
\text { B.2-Case } 3\end{array}$ \\
\hline TF year 0 & \multicolumn{4}{|c|}{ TFno investment cost - all investment is financed with financial debt } \\
\hline TF year 1 & $\mathrm{TF}$ & 22794.00 & 19471.00 & 15686.00 \\
\hline TF year 2 & TF & 22842.00 & 19440.00 & 15748.00 \\
\hline TF year 3 & $\mathrm{TF}$ & 22311.00 & 18978.00 & 15375.00 \\
\hline TF year 4 & $\mathrm{TF}$ & 21793.00 & 18527.00 & 15012.00 \\
\hline TF year 5 & TF & 21845.00 & 18319.00 & 14890.00 \\
\hline TF year 6 & $\mathrm{TF}$ & 20977.00 & 17702.00 & 14357.00 \\
\hline TF year 7 & $\mathrm{TF}$ & 20492.00 & 17282.00 & 14018.00 \\
\hline TF year 8 & $\mathrm{TF}$ & 20018.00 & 16872.00 & 13688.00 \\
\hline TF year 9 & $\mathrm{TF}$ & 19556.00 & 16472.00 & 13365.00 \\
\hline TF year 10 & TF & 31531.00 & 24452.00 & 21421.00 \\
\hline TF year 11 & $\mathrm{TF}$ & 18664.00 & 15700.00 & 15700.00 \\
\hline TF year 12 & $\mathrm{TF}$ & 18234.00 & 15332.00 & 15332.00 \\
\hline TF year 13 & $\mathrm{TF}$ & 17824.00 & 15024.00 & 15024.00 \\
\hline TF year 14 & TF & 17474.00 & 14723.00 & 14723.00 \\
\hline TF year 15 & $\mathrm{TF}$ & 20659.00 & 16593.00 & 16593.00 \\
\hline TF year 16 & $\mathrm{TF}$ & 16798.00 & 14142.00 & 14142.00 \\
\hline TF year 17 & $\mathrm{TF}$ & 16471.00 & 13862.00 & 13862.00 \\
\hline TF year 18 & $\mathrm{TF}$ & 16153.00 & 13589.00 & 13589.00 \\
\hline TF year 19 & $\mathrm{TF}$ & 15842.00 & 13322.00 & 13322.00 \\
\hline TF year 20 & $\mathrm{TF}$ & 15538.00 & 13062.00 & 13062.00 \\
\hline TFBOT Financial results & $\mathrm{TF}$ & 397813.00 & 332865.00 & 298910.00 \\
\hline Financial flow per year (TFy) & & 19891.00 & 16643.00 & 14946.00 \\
\hline Square meters $\mathrm{m}^{2}$ (available per housing) & & 267.00 & 289.00 & 289.00 \\
\hline Financial flow per square meters per year (TFysu) & & 74.50 & 57.59 & 51.71 \\
\hline Financial flow per square meters per year (TFysu) & & $100 \%$ & $77 \%$ & $69 \%$ \\
\hline
\end{tabular}

Source: Our processing of directly collected data 
For the considered cases, given the hypothesis of the availability of $\mathrm{Tb} 2$ (full debt hypothesis, first house case, secured loan with mortgage), the total amount of Tb2 during the 20 years of the loan is $€ 10,161$ discounted for project $\mathrm{A}$ and $€ 9,941$ for project $\mathrm{B}$ (given the different amount paid for house construction at year 0 ). The financial inflow $\mathrm{Tb} 2$ decreasing TFy is $€ 508$ for project A per year, that is, $€ 1.90$ per square meter per year. In the cases B.1 and B.2, Tb2 is $€ 497$, that is, $€ 1.72$ per square meter per year. The analysis of the absorption of total resources $\left(T F_{B}{ }^{O T}\right)$ is performed in Table 9. The outflow for project $A$ is $€ 397,813$, case B.1 has total charges of $€$ 332,865 and case B.2 has total charges of $€ 298,910$. The sustainable technology applied in project $\mathrm{B}$, as well as the result of the tax benefit, reduces significantly the financial year outflow for the building. The annual cash outflow $T F_{y}$ is $€ 19,891$ per year for project A, case B.1 has an annual cash outflow $T F_{y}$ of $€ 16,643$ and case B.2 has an annual cash outflow $T F_{y}$ of $€ 14,946$. The financial flow $\left(T F_{y}{ }^{s u}\right.$ ) output is $€ 74.50$ per square meter per year for project $A, € 57.59$ for case B. 1 and $€ 51.71$ for case B.2.

\section{Discussion}

The application of the LCF model to three house building projects has allowed us to quantify:

- the cash flow $T F_{y}$ and total annual cash flow $T F_{y}{ }^{s u}$ for each project

- the alternative project characterized by a lower absorption of financial resources, that is, alternative B. 2 (sustainable building with "dry" technologies of construction and with tax benefits provided by Italian tax regulations for this type of building construction)

- The absorption of resources (or generation of resources due to tax benefits) at every stage of the life of the building for construction and management by dividing the absorption of resources by nature: Project and construction in the initial phase, energy, servicing, debt service and other costs during the management of the building. This quantification allows us to perform a relative comparison of the minimum absorption of resources, which highlights the advantage of alternative project $\mathrm{B}$ over alternative project $\mathrm{A}$, in particular, with regard to the absorption energy

The analysis also indicated that alternative project B was characterized by technological choices that allowed it to have a greater useful walkable surface; it is then observed, having a greater floor area for residential use in class $\mathrm{B}$ of projects, a reduction, ceteris paribus, of $T F_{y}^{s u}$. In particular, data show that the three project alternatives:

- Placed at $100 \%$ the value $T F_{y}{ }^{s u}$ for alternative project $A(€ 74.50)$, the value of B.1 is $77 \%$ ( $€$ $57.59)$ and the value of B.2 is $69 \%$ (€ 51.71). Analysis then showed that sustainable construction projects B.1 and B.2 had a lower absorption of resources than alternative project $\mathrm{A}$, in both cases: Without tax incentives Tb1 (B.1) and with tax incentives Tb1 (B.2). The weight of tax incentives $\mathrm{Tb} 1$ was still relevant and the weight was $€ 5.87$ for $T F_{y}{ }^{s u}$

- Placed at $100 \%$ FI per square meter for alternative project A (€279), the value of B.1 and B.2 was $84 \%$ $(€ 1,074)$. The sustainable construction projects B.1 and B.2 had a lower absorption of resources than project $\mathrm{A}$, including the project and construction phases, even in the absence of consideration of tax incentives $\mathrm{Tb} 1$

- $\quad$ Placed at $100 \%$ FMe per square meter for alternative project $\mathrm{A}(€ 7.08)$, the value of B.1 and B.2 was $34 \%(€ 2.38)$. The sustainable construction projects B.1 and B.2 had a lower absorption of resources as energy costs compared to alternative project A, even without considering tax incentives $\mathrm{Tb} 1$

- Placed at $100 \%$ FMT per square meter for alternative project $\mathrm{A}(€ 12.46)$, the value of B.1 and B.2 was $45 \%$ (€5.61). Therefore, the sustainable building projects B.1 and B.2 had a lower absorption of resources for the total management charges than alternative project $\mathrm{A}$. In absolute terms, FMT was $€ 66,544$ for project $A$ and $€ 32,436$ for projects B.1 and B.2, with savings for B.1 and B.2 with respect to $A$ of $€ 34,108$ in the 20 years of OT, that is, $€ 1,705$ per year

The analysis showed that, in the specific projects analyzed, the alternative projects using sustainable building (class B) were preferable because they were characterized by lower absorption of financial resources compared to the class A project for three main reasons: (1) Lower absorption of resources for the project and construction; (2) lower energy costs; (3) presence of tax incentives $\mathrm{Tb} 1$ for alternative project B.2. Therefore, the analysis demonstrated that even in the absence of advantages type (2) and (3) of the previous sentence, in cases as analyzed, projects of class $\mathrm{B}$ are preferable compared with projects of class A. The benefits of type (2) and (3) amplify this result.

\section{Conclusion}

The research analysis highlighted how the LCF approach allows us to quantify the uptake of financial 
resources to satisfy housing needs per unit of time and per unit of time and surface area. The analysis showed that sustainable construction using "dry" technologies (projects B.1 and B.2) is less onerous for the consumer and therefore represents a more cost-effective alternative compared to traditional "wet" building construction with a reinforced concrete structure. This quantification is more precise because it considers the entire life of the building. Therefore, LCF reduces the asymmetry of information between the manufacturer and consumer-dweller, improves market efficiency and encourages more informed choices, even in terms of housing choices. For this reason, the approach of LCF applied in this article has an advantage over the traditional LCC approach, by highlighting the time of financial outflows and therefore representing a useful tool for assessing the financial viability of property investment, particularly for private consumers. The LCF approach is useful, as in the cases reviewed in this article, for debt repayment analysis (loan subscribed to finance a house purchase) and a consequent need to assess the financial sustainability of debt for consumers. However, LCF is no more useful than the LCC approach in cases where there is no time lag between costs and cash outflows, or the time lag is negligible. The LCF approach has subjectivity that are: (1) The prediction of outflows over time; (2) the quantification of the inflation rate and the discount rate applicable; (3) the determination of the time horizon (OT) and the presence of any outflows over OT, in addition to the possible effect of different OT between different alternative projects considered in the comparison; (4) the need to consider the time of construction and related financial expenses, even implicit, for the use of capital; (5) the presence of any unexpected charges due to the application of technologies or plant new and untested for durations in OT; (6) the consideration (or lack of consideration) of transaction costs related to investment property, such as costs of transferring ownership and/or expenses related to the signing of loans for financing the property and/or charges related to the preparation of tax returns for $\mathrm{Tb} 1$ and $\mathrm{Tb} 2 ;(7)$ the presence of possible claims by tax agencies related to tax requirements, with related effects on the values $\mathrm{Tb} 1$ and $\mathrm{Tb} 2$ during the OT period. These elements (from 1 to 7) make the application of the LCF model (as well as the application of the LCC model) subject to variability and subjectivity of results that should be defined, if possible, during the construction of the model and dissemination of the results to the consumer, in the choice of housing. Furthermore, we should consider that when a consumer chooses a house, there are many other aspects to consider, in addition to the purely economic element, thus, in order to implement the consumer's choice, it is necessary to consider LCF as the outcome, although useful, but only one of the elements that forms the basis of the consumer's choice regarding the satisfaction of housing needs. Given the results of the research and limitations as defined, the LCF model can be developed and further applied, in particular, to quantify social welfare generated by tax benefits financed with public spending, in terms of economic activation and assessing environmental externalities and even deepening the concept of sustainability applied to residential building.

\section{Acknowledgement}

The researchers would thank analisiaziendale.it for IT assistance, particularly in the database management.

\section{Author's Contributions}

The article is a result of the full collaboration of all the authors.

Mattia Iotti: He wrote paragraphs Materials and methods: Life Cycle Cost (LCC) and Life Cycle Flow (LCF) approaches, Results, Conclusion.

Giuseppe Bonazzi: He wrote paragraphs Introduction, Materials and methods: Literature review, Discussion.

\section{Ethics}

The authors have no conflicts of interest in the development and publication of current research.

\section{References}

Al Omiri, M. and C. Drury, 2007. A survey of factors influencing the choice of product costing systems in UK organizations. Manage. Account. Res., 18: 399-424. DOI: 10.1016/j.mar.2007.02.002

Argyris, C. and R.S. Kaplan, 1994. Implementing new knowledge: The case of activity-based costing. Account. Horizons, 8: 83-105.

Artto, K.A., 1994. Life cycle cost concepts and methodologies. J. Cost Manage., 8: 51-64.

Asiedu, Y. and P. Gu, 1998. Product life cycle cost analysis: State of the art review. Int. J. Product. Res., 36: 893-908. DOI: 10.1080/002075498193444

Askarany, D. and M. Smith, 2003. The relationship between technological innovation, activity-based costing and business size. Inform. Sci., 1: 865-882.

Bonazzi, G. and M. Iotti, 2015. Evaluation of biogas plants by the application of an internal rate of return and debt service coverage approach. Am. J. Environ. Sci., 11: 35-45. DOI: 10.3844/ajessp.2015.35.45 
Chinnici, G., B. Pecorino and A. Scuderi, 2013. Environmental and economic performance of organic citrus growing. Quality Access Success, 14: 106-112.

Ciroth, A., K. Verghese and C. Trescher, 2008. A Survey of Current Life Cycle Costing Studies. In: Environmental Life Cycle Costing, Hunkeler, D., K. Lichtenvort and G. Rebitzer (Eds.), SETAC-CRC, Pensacola, ISBN-10: 188061138X. pp: 91-111.

Cooper, R. and R.S. Kaplan, 1991. Profit priorities from activity-based costing. Harvard Bus. Rev., 69: $130-135$.

Cooper, R. and R.S. Kaplan, 1992. Activity-based systems: measuring the costs of resource usage. Account. Horizon, 6: 1-13.

Cooper, R. and R.S. Kaplan, 1999. The Project of Cost Management Systems. 1st Edn., Prentice Hall, New York.

Costa, M. and G. Guzzo, 2013. Fair value accounting versus historical cost accounting: A theoretical framework for judgment in financial crisis. Corporate Ownership Control, 11: 146-152.

De Gennaro, B., B. Notarnicola, L. Roselli and G. Tassielli, 2012. Innovative olive-growing models: An environmental and economic assessment. J. Cleaner Product., 28: 70-80.

DOI: $10.1016 /$ j.jclepro.2011.11.004

De Luca, A.I., G. Falcone, T. Stillitano, A. Strano and G. Gulisano, 2014. Sustainability assessment of quality-oriented citrus growing systems in Mediterranean area. Quality-Access Success, 15: 103-108.

De Luca A.I., N. Iofrida, A. Strano, G. Falcone and G. Gulisano, 2015. Social life cycle assessment and participatory approaches: A methodological proposal applied to citrus farming in Southern Italy. Integrated Environ. Assessment Manage., 11: 383-396. DOI: 10.1002/ieam.1611

Debnath, S. and S.K. Bose, 2014. Exploring full cost accounting approach to evaluate cost of MSW services in India. Resources Conservat. Recycl., 83: 87-95. DOI: 10.1016/j.resconrec.2013.12.007

Dhillon, B.S., 1989. Life Cycle Costing: Techniques, Models and Applications. 1st Edn., Psychology Press, ISBN-10: 2881243029, pp: 353.

Di Trapani, A.M., R. Squatrito, M. Foderà, R. Testa and S. Tudisca et al., 2014. Payment for environmental services for the sustainable development of the territory. Am. J. Environ. Sci., 10: 480-488.

DOI: 10.3844/ajessp.2014.480.488

Fabrycky, W.J. and B.S. Blanchard, 1991. Life-Cycle Cost and Economic Analysis. 1st Edn., Prentice Hall, Englewood Cliffs, ISBN-10: 0135383234, pp: 384.
Falcone, G., A. Strano, T. Stillitano, A.I. De Luca and N. Iofrida et al., 2015. Integrated sustainability appraisal of wine-growing management systems through LCA and LCC methodologies. Chem. Eng. Trans., 44: 223-228. DOI: 10.3303/CET1544038

Fedele, A., A. Mazzi, M. Niero, F. Zuliani and A. Scipioni. 2014. Can the life cycle assessment methodology be adopted to support a single farm on its environmental impacts forecast evaluation between conventional and organic production? An Italian case study. J. Cleaner Product., 69: 49-59. DOI: 10.1016/j.jclepro.2014.01.034

Gluch, P. and H. Baumann, 2004. The Life Cycle Costing (LCC) approach: A conceptual discussion of its usefulness for environmental decision-making. Build. Environ., 39: 571-580.

DOI: 10.1016/j.buildenv.2003.10.008

Hedeşiu, D., S. Popescu and A. Petruş, 2012. Generic structure for quality costs in life-cycle approach. Quality-Access Success, 13: 161-174.

Imperadori, M., 2008. La progettazione con tecnologia stratificata a secco. IlSole24-Ore, Milano

Iotti, M. and G. Bonazzi, 2014a. Life cycle flow analysis: Methodological improvement and application to the Parma PDO ham sector. Quality Access Success, 15: 98-103.

Iotti, M. and G. Bonazzi, 2014b. The application of Life Cycle Cost (LCC) approach to quality food production: A comparative analysis in the Parma PDO ham sector. Am. J. Applied Sci., 11: 1492-1506. DOI: 10.3844/ajassp.2014.1492.1506

Iotti, M. and G. Bonazzi, 2015. Application of ICRs with a Net Financial Position (NFP) repayment approach in the Parma PDO ham sector. J. Food Agric. Environ., 13: 109-114.

ISO, 2008. BS ISO 15686-5:2008 -Buildings and constructed assets-Service life planning-Life Cycle Costing.

Kallunki, J.P. and H. Silvola, 2008. The effect of organizational life cycle stage on the use of activitybased costing. Manage. Account. Res., 19: 62-79. DOI: 10.1016/j.mar.2007.08.002

Korpi, E. and T. Ala-Risku, 2008. Life cycle costing: a review of published case studies. Managerial Audit. J., 23: 240-261. DOI: 10.1108/02686900810857703

Lanfranchi, M. and C. Giannetto, 2014. Sustainable development in rural areas: The new model of social farming. Quality Access Success, 15: 219-223.

Lichtenvort, K., G. Rebitzer, G. Huppes, A. Ciroth and S. Seuring et al., 2008. History of Life Cycle Costing, Its Categorization and its Basic Framework. In: Environmental Life Cycle Costing, Hunkeler, D., K. Lichtenvort and G. Rebitzer (Eds.), SETAC-CRC, Pensacola, ISBN-13: 9781420054705, pp: 1-16. 
Lopolito, A., G. Nardone, M. Prosperi, R. Sisto and A. Stasi, 2011. Modeling the bio-refinery industry in rural areas: A participatory approach for policy options comparison. Ecol. Econom., 72: 18-27. DOI: $10.1016 /$ j.ecolecon.2011.09.010

Notarnicola, B., E. Settanni and G. Tassielli, 2009. Approcci all'integrazione dei costi in LCA: Life Cycle Costing, analisi Input-Output. In: Atti del Convegno Scientifico della Rete Italiana LCA, Palermo 11 e 12 giugno, Cappellaro, F. and S. Scalbi, (Eds.), ENEA, Roma, ISBN-13: 978-88-8286-206-0, pp: 17-25.

Notarnicola, B., G. Tassielli and G.M. Nicoletti, 2004. Environmental and economic analysis of the organic and conventional extra-virgin olive oil. New Medit, 2: 28-34.

Pong, C. and F. Mitchell, 2006. Full costing versus variable costing: Does the choice still matter? An empirical exploration of UK manufacturing companies 1988-2002. Brit. Account. Rev., 38: 131-148. DOI: 10.1016/j.bar.2005.09.003

Rebitzer, G. and S. Seuring, 2003. Methodology and application of life cycle costing. Int. J. LCA, 8: 110-111. DOI: $10.1007 / \mathrm{BF} 02978436$

Sarno, V. and M. Barmo, 2014. Sustainability management in the agri-food companies: A practical guide. Quality Access Success, 141: 96-99.

Schiffauerova, J.J. and B.G. Dale, 2006. A review of research on cost of quality models and best practices. Int. J. Quality Reliability Manage., 23: 647-669. DOI: 10.1108/02656710610672470

Sgroi, F., S. Tudisca, A.M. Di Trapani, R. Testa and R. Squatrito, 2014. Efficacy and efficiency of Italian energy policy: The case of PV systems in greenhouse farms. Energies, 7: 3985-4001. DOI: $10.3390 /$ en 7063985
Shim, E. and A. Stagliano, 1997. A survey of US manufacturers on implementation of ABC. J. Cost Manage., 12: 39-41.

Srivastava, S.K., 2008. Towards estimating cost of quality in supply chains. Total Quality Manage. Bus. Excellence, 19: 193-208. DOI: $10.1080 / 14783360701600605$

Strano, A., A.I. De Luca, G. Falcone and G. Gulisano, 2013a. Economic and environmental sustainability assessment of Clementine crops scenarios in Calabria. Proceedings of the 50th SIDEA Conference Lecce, Chiostro dei Domenicani, Sept. 26-28.

Strano, A., A.I. De Luca, G. Falcone, N. Iofrida and T. Stillitano et al., 2013b. Economic and environmental sustainability assessment of wine grape production scenarios in Southern Italy. Agric. Sci., 4: 12-20. DOI: 10.4236/as.2013.45B003

Strano, A., T. Stillitano, A.I. De Luca, G. Falcone and G. Gulisano, 2015. Profitability analysis of smallscale beekeeping firms by using Life Cycle Costing (LCC) methodology. Am. J. Agric. Biol. Sci. DOI: $10.3844 /$ ofsp. 10034

Troiano, S. and F. Marangon, 2010. Payments for Ecosystem Services: Development opportunities from landscape and environmental resources management. Econom. Policy Energy Environ., 3: 87-113.

Tudisca, S., A.M. Di Trapani, F. Sgroi, R. Testa and R. Squatrito, 2013. Economic analysis of PV systems on buildings in Sicilian farms. Renewable Sustainable Energy Rev., 28: 691-701. DOI: $10.1016 /$ j.rser.2013.08.035

Yoshikawa, T., J. Innes and F. Mitchell, 1994. Functional analysis of activity-based cost information. Cost Manage., 3: 40-48. 